\title{
Forced and Unfree Labour: An Analysis
}

By

\author{
Jamie Morgan and Wendy Olsen
}

Please cite this article as:

Morgan, J., and W. Olsen, 2014, "Forced and Unfree Labour: An analysis", International Critical Thought, 4:1, 21-37, DOI:10.1080/21598282.2014.878144.

Please refer to the publisher's website as shown above (http:// 10.1080/21598282.2014.878144) to get the article in full. This version is before the proof version was corrected.

\section{Forced and Unfree Labour: An Analysis}

BY:

Jamie Morgan $^{\mathrm{a}^{*}}$ and Wendy Olsen ${ }^{\mathrm{b}}$

${ }^{\mathrm{a}}$ the Association for Heterodox Economics, Accountancy, Finance and Economics Department, Leeds Metropolitan University, Leeds, UK; ${ }^{\mathrm{b}}$ Social Statistics Discipline Area, University of Manchester, Manchester, UK (Full author details at end of this document)

In 2011 the UN International Labour Organization produced a new estimate of 20.9 million victims of forced labour (ILO, 2012: p. 16). Forced labour continues to be found in almost all countries and all economic sectors. This persistence and development of forced labour raises various issues that we explore in this paper. It is free labour that is central to the Marxist account of capitalism, both in terms of its economic and ideological dynamics. There is, therefore, a potential tension for Marxist theory in terms of the persistence and diversification of forced labour and we explore this, drawing also on the 'realist' concepts of agency and structure. For forced labour to flourish, as clearly it is, there must also be a combination of motive and opportunity in the contemporary world. One can, therefore, ask what kind of capitalism promotes forced labour.

Keywords: forced labour; unfree labour; ILO; neo-liberalism; Archer

JEL codes

J70 - Labour Discrimination - General

J47 - Coercive Labour Markets

B50 - Heterodox Approaches

Since 2010 Anti-Slavery International has championed the $18^{\text {th }}$ October as anti-slavery day in an attempt to raise awareness of this continuing global blight. In 2011 the United Nations International Labour Organization (ILO) introduced a new methodology for calculating the numbers of victims of forced labour, producing a new estimate of 20.9 million (ILO, 2012: p. 16). Forced labour is found in every region of the world and in many different contexts. It has developed far beyond the general Marxist association of unfree labour with a precapitalist mode of production, and where practices creating and using unfree labour seem destined to whither away as the institutions of capitalism come to dominate. This persistence and development of forced labour raises two conceptual issues. First, what kind of capitalism promotes forced labour? Second, what theory of social reality can contribute to a Marxist conceptualisation of the persistence and development of forced labour? We approach these two questions in four sections. In section 1, we briefly set out how forced labour is approached by the ILO. In section 2, we contextualise the issue of forced and unfree labour with reference to debate within the political economy of development studies. In section 3, we set out how realist social theory might contribute to exploring the problem of forced labour and in section 4, we set out different aspects of neoliberalism that serve to facilitate forced labour.

\footnotetext{
*Corresponding author. Email: jamiea.morgan@ @otmail.co.uk
} 


\section{The ILO approach to forced labour}

The ILO concept of forced labour has been evolving since the original Forced Labour Convention of 1930 (see ILO, 2005; ILO, 2009). Forced labour is defined as work that is entered into on a non-voluntary basis and where the work is done under some form of duress (the menace of a penalty). Forced labour is not equated with taking employment because of economic necessity and experiencing low wages and relatively poor working conditions or with feeling unable to relinquish a job because of lack of alternatives. More must be involved. This can begin with coercion but forced does not necessarily mean being coerced into taking employment and coerced into remaining within it. It extends also into deception and psychological menace. Importantly, there must be some recognizable violation of human rights and restriction on freedom. The ILO tends to look at these in terms of indicators and emphasises that the violation and the restriction are matters of degree and are found in many different contexts. The point of emphasising degree is that forced labour can shade into situations one might want to describe as highly exploitative but not necessarily forced. The benchmark in either case is the ILO concept of decent work (ILO 1999; Ghai, 2006: pp. 4-22), defined in terms of reasonably/adequatelyremunerated secure, productive, and dignified work, subject to social protection, and extending to the creation and enforcement of individual rights and collective forms of representation within some form of recognized and valued genuine social dialogue. Forced labour is then categorised into 3 groupings (see e.g. ILO senior analyst Belser, 2005):

- Imposed by the state/state challenging rebel factions - typically for military purposes or for public works

- Commercial sexual exploitation (CSE) - typically forced prostitution of adults and children

- Non-sexual economic exploitation (EE) - see below

The ILO further sub-categorises forced labour in terms of whether human trafficking is present. Human trafficking is defined by the UN 'Palermo Protocol' of 2000 as the 'threat or use of force, coercion, abduction, fraud, deception, abuse of power or vulnerability' to expedite the transfer of persons, domestically or internationally. The trafficking may itself be a form of exploitation and/or may be for the purposes of further exploitation through forced labour at the point of destination.

Using the above categories the 2012 re-estimation of numbers of forced labour victims by the ILO breaks down the initial 20.9 million figure in a variety of ways. Twenty six percent of the total numbers of victims across the 3 main categories are children. The overwhelming majority are forced labourers in the private economy, of which 4.5 million are victims of forced sexual exploitation (CSE) and 14.2 million are victims of other forms of economic exploitation (EE). ${ }^{\mathrm{i}}$ Across all 3 main categories 9.1 million are trafficked. The categories then encompass many situations. For example (for specific case studies see ILO 2009, Chp. 2; ILO, 2013; Global Dialogue 2012, special issue on slavery e.g. Mantouvalou; Global Labour Journal 2012, special issue e.g. Geurin et al.):

- Where adults or children are deceived into accepting fictitious employment in some other region or nation, are trafficked, and then put to work as a prostitute, whilst their documents are witheld and a transport and maintenance debt is applied by the trafficker or employer who controls that debt.

- Where adults or children are contracted to become domestic labour for wealthy households and the conditions of service are not as initially represented: documents and wages are withheld, sexual harassment occurs, living conditions are basic, hours are unrestricted and threats of physical or official (police, immigration etc.) sanction are used to create control.

- Where adults or children are contracted to become labour in supply chains for goods and services but sweatshop conditions apply, the labour may be sub-contracted to a gangmaster, the worker may be compelled to work without attention to existing health and safety regulation, and be denied formal employment rights (due to sub-contraction), whilst being paid below the going/legal rate otherwise set for the factory, industry, or state. 
- Where families are tied to rural farming servitude through traditional and typically inter-generational, debt bondage: a landlord holds a debt over tenants and those tenants are compelled to do additional work for the landlord on land not leased to the tenant, or in domestic servitude to the landlord in order to maintain access to the tenancy and to service the debt, however the debt is poorly specified and controlled by the landlord.

- Where children are offered up as collateral for loans or in payment of debt and become subject to any of the main forced labour categories.

Though the examples encompass many situations it is the commonalities or generalisable features that the ILO uses as the basis of indicators for forced labour (e.g. ILO 2005: p. 6; ILO 2009, p. 13). Key indicators include the retention of documents, the use of physical or sexual violence, isolation, confinement or restriction on movement, threats of official sanctions from state authorities, threats against family, extensive discretion over the timing and value of any payments to labour, and the control and manipulation of debt as a form of bondage based on the 1956 UN Supplementary Convention on the Abolition of Slavery definition as 'the status or condition arising from a pledge by a debtor of his personal services or of those under his control as security for a debt, if the value of those services as reasonably assessed is not applied towards the liquidation of the debt or the length and nature of those services are not respectively limited and defined' (UN, 1957: p. 41). The existence of two or more indicators is typically considered to be strong evidence of forced labour. ${ }^{\text {ii }}$

So then, forced labour involves some combination of coercion/deception in terms of entry into work, an inability to readily exit work because of some mechanism of entrapment, and subjection to conditions of work that are harmful to well-being and that may amount to slavery. Since this activity violates general UN member commitments (e.g. Article 23 of the Universal Declaration of Human Rights) and ILO conventions, ratified by the majority of states and internalised in regional and national statute, it is essentially illegal almost everywhere. For forced labour to flourish, therefore, as clearly it is, there must be a combination of motive and opportunity in the contemporary world. The motive is clear, forced labour is extremely profitable. In 2005, based on the then ILO estimated level of global forced labour of 12.3 million, Belser calculated minimum annual profits at US\$ 44.2 billion (Belser, 2005: p. 16). Given that the 2012 re-estimation increased the numbers of victims by $70 \%$ then the actual figure for profitability in 2012 and onwards is likely far in excess of US\$ 44.2 billion. This profitability moreover is spread across many sectors of economy. This means that, despite its illegality, forced labour is a viable alternative to the employment of voluntary labour in many situations.

According to the 2012 ILO estimate the greatest regional concentration of victims of forced labour, 11.7 million, are found in Asia (ILO, 2012: p. 16): 
Figure 5. Estimate of forced labour by region

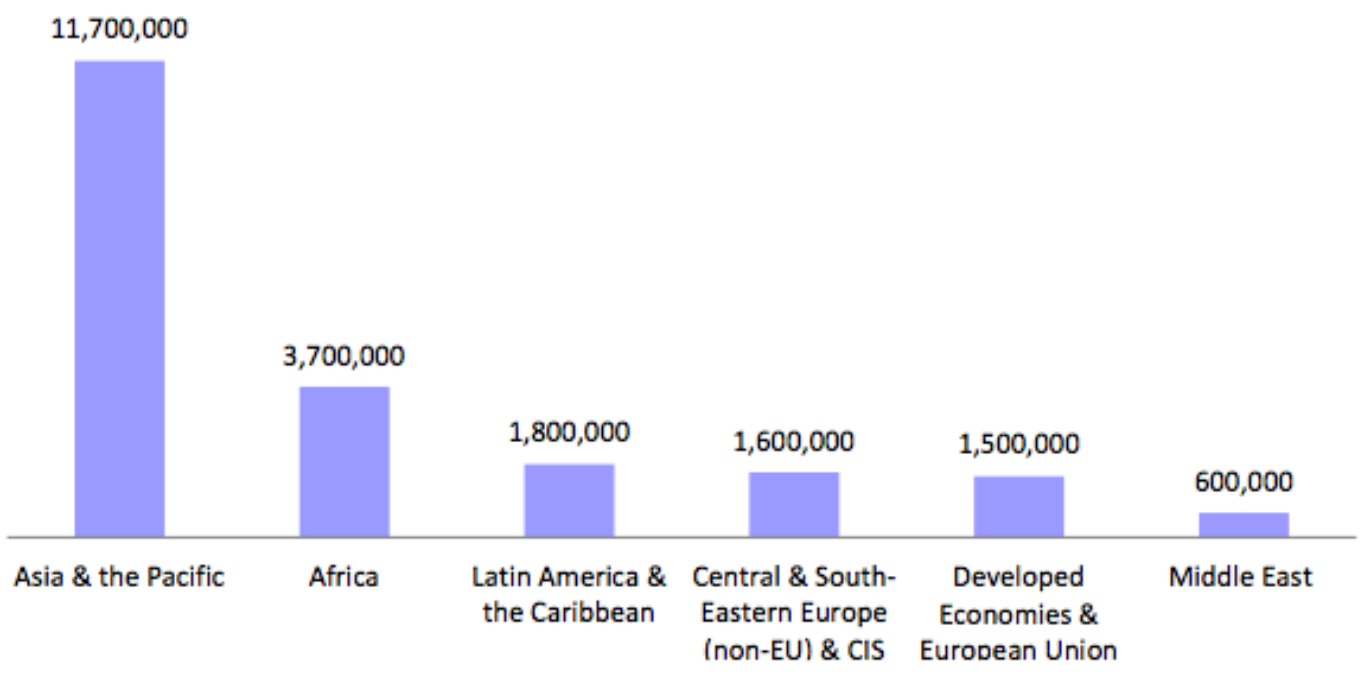

The great majority of victims in Asia are spread across India, Bangladesh, Pakistan, Indonesia, Myanmar, and the Philippines. Of these the greatest numbers are found in traditional rural debt bondage working as tenants in agriculture. But they are increasingly found in different varieties of forced labour in different sectors of economy - from CSE to many forms of EE. As the ILO noted in 2005:

Older forms of coercion and compulsion are transmuting into newer ones. The bonded labour systems of South Asia remain very much in evidence today, and account for the greatest number of forced labourers in the contemporary world. But these systems have changed over the past three or four decades. They now pervade different sectors of the informal economy, as well as the agricultural sector, where the lion's share of bonded labour was previously found. (ILO 2005: p. 1)

As such economic development, capitalist integration, and globalization have not resulted in a discernable end to forced labour. This raises the question, what is it about modern capitalism that enables opportunity to exist? There is also a potential conceptual tension here for Marxists since forced labour is unfree and the Marxist understanding of capitalism as a mode of production begins from the centrality of free labour.

\section{The centrality of free labour and the concept of unfree labour}

Marx's focus in Capital is on the centrality of the role of free labour in (though of course he does not use the term) capitalism as a mode of production. The worker is free in the formal sense to contract to provide labour to any capitalist. At the same time the worker is subject to the material realities of capitalism and s/he is free to starve or suffer if s/he does not work. As Marx puts it in volume one of Capital a worker is 'compelled to sell himself of his own free will' (1954: p. 766). Mobile and motivated free labour is forced to sell her labour power within the prevailing system and accepts wages within a market, dominated by the capitalist. A labour market is thus an expression of the treatment of labour as a commodity. Labour has an exchange value, expressed as wages. The wage system and market for labour as a commodity serves to disguise that profit is based on the extraction of surplus value. Free labour is then a key constituent in the system of capitalism as an economic form but also a key constituent in the ideological reproduction of capitalism. As such, free labour is not just an aspect of structure it is also integral to superstructure. It is the socialisation of the human with a focus on the individual, interest, and sense of freedom to act (vote, consume, aspire, and achieve through work) created by a capitalist system that as Althusser later elaborated (and which does not require one to be a structural Marxist to accept) provides for 'the reproduction of the conditions of production' (Althusser, 1971: p. 127), and in turn provides also 'the institutional conditioning for the reproduction of the skills of labour power' (Althusser, 1971: p. 133). The consequence is that: 
The individual is interpellated as a (free) subject in order that he shall submit freely to the commandments of the Subject, i.e. in order that he shall (freely) accept his subjection, i.e. in order that he shall make the gestures and actions of his subjection 'all by himself'. (Althusser, 1971: p. 182)

And as Marx and Engels put it in the German Ideology:

The modern State, the rule of the bourgeoisie, is based on freedom of labour.... With freedom of labour, not I become free, but only one of my enslavers. Freedom of labour is free competition of the workers among themselves... Labour is free in all civilised countries; it is not a matter of freeing labour but of abolishing it' (Marx \& Engels, 1968: 223-224)

So, for Marxists free labour is exploitative because capitalism is exploitative but it is not thereby unfree in the sense the ILO associates with forced labour. As such, the existence of forced labour requires some further consideration for Marxists. It is free labour that is central to the Marxist account of capitalism, both in terms of its economic and ideological dynamics. The very existence of forced labour brings into question the legitimacy of capitalism based on the role of institutions in regard of capitalism's ideological expression.

A useful place to start here is to acknowledge that Marx recognizes the existence of forms of forced labour within historical-contemporary capitalism. For example, in Chapter 15 of volume one of Capital Marx argues that the introduction of machinery places downward pressure on wages causing household labour power to be sold collectively and in ways that are clearly unfree for some within the institutional arrangements and opportunities of the time:

Machinery also revolutionises out and out the contract between the labourer and the capitalist, which formally fixes their mutual relations. Taking the exchange of commodities as our basis, our first assumption was that capitalist and labour met as free persons, as independent owners of commodities the one possessing money and means of production, the other labour-power. But now the capitalist buys children and young persons under age. Previously, the workman sold his own labour-power, which he disposed of nominally as a free agent. Now he sells his wife and child. He has become a slave-dealer. The demand for children's labour often resembles in form the inquiries for negro slaves, such as were formerly to be read among the advertisements in American journals. (Marx, 1954: p. 396)

One can then read from Marx that forced labour or unfreedom may not be central to capitalism but it is not inimical to it. In this instance it is the free situation of poverty within capitalism that compels an unfree outcome. But it remains the case that the persistence of forced labour must be unsettling within capitalism in terms of reproduction and legitimation. As such one might consider forced labour as a vestige of pre-capitalist relations and as a characteristic of primitive capitalism - its early stages before the institutions necessary to its reproduction gain maturity.iii The problem with this, however, is that it does not accord with reality, as the ILO evidence clearly indicates. Forced labour is found in almost every country and in many different sectors of economy. This has motivated debate within development studies, for example, about how to view both the continuation of rural debt bondage in some countries and the emergence of forced labour in factories, domestic labour and so forth.

Rao, for example, argues that unfree labour is not compatible with capitalism in the long run (e.g. Rao, 1999). Free and unfree labour manifestly co-exists, but unfree labour is alien to the labour process within capitalism. It cannot persist indefinitely. Brass, in contrast, argues that forms of unfree labour can become part of the labour process and can serve a systemic function within capitalism (e.g. Brass, 2002; 1999). His focus is on the shift in circumstances for victims of traditional rural debt bondage, who now find themselves incorporated into the labour process based on forms of forced labour, for example, as workers in supply chains for goods and services where sweatshop conditions apply. He argues that forced labour is not just profitable it can be functional in modern capitalism, creating a de-proletarianising effect: 
Deproletarianisation occurs as a result of workforce restructuring, a form of class composition/decomposition/recomposition which accompanies the struggle between capital and labour, and a process whereby employers introduce or reintroduce unfree relations. This is effected either by replacing free workers with unfree equivalents, or by converting the former into the latter. The advantages of deproletarianisation are twofold. Economically, such restructuring enables capitalist producers to lower the cost of free workers by employing more easily regulated, and thus cheaper, unfree labour. Ideologically, its purpose - in both metropolitan capitalist countries and third world contexts - is to prevent the emergence of specifically proletarian consciousness. (Brass, p. 465)

Brass's underlying point is that forced labour as unfreedom is not incompatible with historical capitalism. Free labour is the core of Marx's account of capitalism in the abstract but it is not the last word on the complexity of real capitalism. Banaji, also emphasizes the complexity of real capitalist systems (2003). In order for capitalism to be capitalism, free labour must be in reality the dominant characterisation of work. At the same time, Marxism can recognize degrees of exploitation within free labour and this can shade into unfreedom. The nature of contracts, the power of ideology and the way in which the sphere of economy is constructed within capitalism indicate that one cannot rely on a binary categorisation of free and unfree labour, where each is defined as what the other is not. For a Marxist, the very notion of free choice in the employment bargain is a fiction of the concept of the autonomous individual within capitalism. For Banaji, a simple 'line between free and unfree labour is impossible to draw' (2003: p. 72); there is a clear link here to the ILO focus on issues of degree in forced labour situations that can shade into situations one might want to characterise as highly exploitative but not forced. Capitalism can operate through multiple forms of exploitation, including those that involve forced labour. Manifestly these can also involve complex interactions with culture, morality, and law, creating grounds for commercial sexual exploitation (CSE), and grounds for forms of forced labour as economic exploitation (EE). These are not restricted to developing country situations, they can emerge in and/or be exported to 'advanced' capitalist countries.

As Lerche makes clear (2007), all the contributions within development studies share important common features (see also Bremen, e.g. 2007, Bhandari, 2008 and others). All acknowledge the empirical reality of forms of forced labour, as understood by the ILO. Much of the immediate argument turns on matters of category and definition. As Banaji makes clear a great deal of the debate here is oxygenated by a binary classification. The more binary positions hold that unfree labour by definition cannot be capitalist. But this requires a rather thin reading of Marx that fails to distinguish between capitalism in the abstract, focused on free labour, and the acknowledged complexity of real historical capitalism. At the same time the recognition that free labour (with its exploitations) is central to capitalism and that forced labour creates problems of legitimation for capitalism tends to lend credence to the argument that capitalism through its institution building is at least formally antithetical to forced labour and unfreedom.

The tension here, however, is apparent rather than real. In a significant sense forced and unfree labour contradict central tenets of capitalism - its formalisitic and legalistic articulation of the autonomous individual as a carrier of rights within a progressive society. But capitalism is replete with contradictions and tensions, not least in the way it distributes freedoms (Cohen, 1995). Moreover, for a Marxist, the engine of capitalism is the pursuit of profit in a competitive system, which socialises the treatment of individuals as distanced, alienated, and commodified objects. As the ILO statistics indicate, profit can motivate forced labour and as the very need for the many publicity campaigns of the ILO also illustrate, capitalism allows some of us to treat others as objects and some of us to ignore that objectification. It may be the case that institution building within the state and within global capitalism requires that forced labour and unfreedom be prohibited, and that organizations work to eradicate its forms. But capitalism also provides a profit motive for the use of forced labour and also, through its socialisations creates a mentality within which laws are circumvented. The very existence of the ILO, the transmission of its conventions and its simultaneous role in publicising the persistence of forced labour illustrate this. The ILO is almost a century old, its basic conventions regarding issues like slavery and quasi-slavery have 
not become redundant rather they themselves have had to be adapted. The UN Palermo Protocol on human trafficking is just one instance of this.

The issue of free labour and legitimacy is then not one that provides a strong argument that forced labour is a vestige of pre-capitalist relations and will necessarily whither away as capitalism develops. Forced labour unfreedom - is an empirical reality; it is one potentially sustained by the contradictions of capitalism and by the innovative nature of capitalism (some of which Marx was in no position to recognize, providing also a reason neither to reify Marx or read him thinly in a way that overly restricts thinking about the substantive forms of forced labour). One might more appropriately consider forced labour and unfreedom as an ever-present possibility within capitalism, even though some of its forms predate capitalism. It cannot be the dominant characteristic because then capitalism would not be capitalism but it can be an aspect of capitalism. Forced labour can grow or diminish and can emerge in many situations. This invites the question, what type of capitalism makes forced labour more likely? But it also provokes a further conceptual elaboration. Forced labour and unfreedom may not be incompatible with a Marxist approach to historical-contemporary capitalism, but it would be useful to consider how to conceptualise this real capacity for forced labour to grow and diminish.

\section{Realist social theory and agency and structure}

Marxism's great strength is that it is a 'theory of the social totality, and of the relations existing between the economy and the other instances of the social whole', (Callinicos, 1985: p. 15). However, it is also the case that some aspects of the relations and whole are not fully elaborated within the work of Marx and Engels and that this has caused ongoing debate. Gouldner (1980), for example, highlights the core tension between the scientific credentials of Marxism, sometimes problematically read as a form of determinism (e.g. there is a clear direction of development within history) and its critical dimension as a form of contingency (e.g. the critique of capitalism includes also the eradication of false consciousness and the need to make a particular kind of future happen through socio-political action). The potential for different emphases and interpretations here has been both an academic issue and, in terms of the Internationals of the twentieth century, a political one. One aspect of the tension has concerned how to make sense of the issue of determination and contingency based on the problem of agency and structure. It is a commonplace of Marxism that 'Men make their own history, but they do not make it just as they please; they do not make it under circumstances chosen by themselves, but under circumstances directly encountered and transmitted from the past' (Marx in Marx and Engels, 1950: p. 225).

Realist social theory provides one useful way to elaborate on the problem of agency and structure in regard of the issue of forced labour. Realist social theory emerged from the British Left in the 1970s in response to issues in the philosophy of science and developed thereafter as a counter to post-modernism (see e.g. Keat and Urry, 1975; Bhaskar, 1975; Callinicos, 1989). It is centrally focused on reconciling the problems of determinism and contingency. This is relevant to the problem of forced labour because one underlying issue is how to conceptualise the way forced labour can grow and diminish.

If we think of unfreedom as an outcome, then it is not itself a structure, it is the consequence of a pattern of working in which there is a degree of exploitation, which may include characteristics (e.g. the ILO indicators) such that we categorise the variety of work as forced labour. Individuals or households experience the forced labour but the creation of the situation requires multiple actors. People are positioned to act in different ways and one can ask what kind of person or household is likely to become a subject of specific practices, such as varieties of forced labour. This is an issue of how vulnerability is created, and how choices are channelled and restricted. Here, specific work practices are rooted also in further structures of social relations that manifest in vulnerabilities and the restriction of choice. For example, through issues of education, financial resources, social class, gender, ethnicity, place of origin, caste, and other internalised sets of norms of behaviour that differentiates life chances (e.g. Olsen and Morgan 2010; Morgan and Olsen, 2011a; 2011b). 
One can think of agency as embedded but also distinct from a mix of structures. The agent has causal power (for original argument see Harre and Madden, 1975) but as Marx well understood the nature of choice is constructed and shaped by structures. Significantly, realism focuses on how both structure and agency are complex and changing. Archer, for example, refers to the process as morphostasis/morphogenesis (1995) and realists refer in general to a transformational model of social action (TMSA). The approach has several key characteristics. First, following Marx, society and individuals are related but distinguished. Individuals are socialised and thus the structures they encounter and act in regard of help to shape them. However, their activity can reproduce the central aspects of how they are socialised or can modify them. Agency is distinct from structure despite that structure only exists because agents exist to conceive of those structures. The two must be distinguished in order to avoid collapsing the agent into a purely socialised dupe and structure into a mere aggregation of agent actions (becoming a heap rather than a durable yet contingent context)

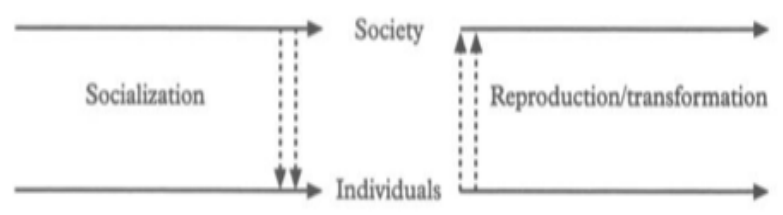

(see Archer, 1995: p. 155)

Within the approach the relation is temporal. Each act of social engagement has an outcome that becomes part of the conditions of future agency. This process is far broader than simply the intent and understanding of the agent or the impact on the specific choice of the agent. The overall mix of influences upon the agent may be poorly conceived or considered by that agent, though it may simultaneously have a narrow set of understood goals and intentions. For example, the agent working under forced labour conditions in a sweatshop has not set out to reproduce sweatshops, but rather to alleviate their own poverty. At the same time, the other influences that brought them to that situation may be also reproduced. A child at work is not at school. A child working for little or no pay may contribute to household income but also to adult unemployment and the undermining of the development of a formal economy. Vulnerability and narrowed choices may then also have wider unintended consequences. The very reproduction of poverty and vulnerability may make for further expansion of forms of exploitation, such as the growth of an economic sector based on forms of forced labour. As such, vulnerability can be transferred from one sector to another as it grows. Someone is required to make that transfer and this invites a focus on other agents who are exploiters, such as gangmasters or traffickers. The existence, for example, of bonded labour in agriculture creates a vulnerable group whose labour can be transferred to sites of new economic development (sweatshops) or to new opportunities for exploitation (CSE through sex tourism). Archer maps out the agent structure interaction as:

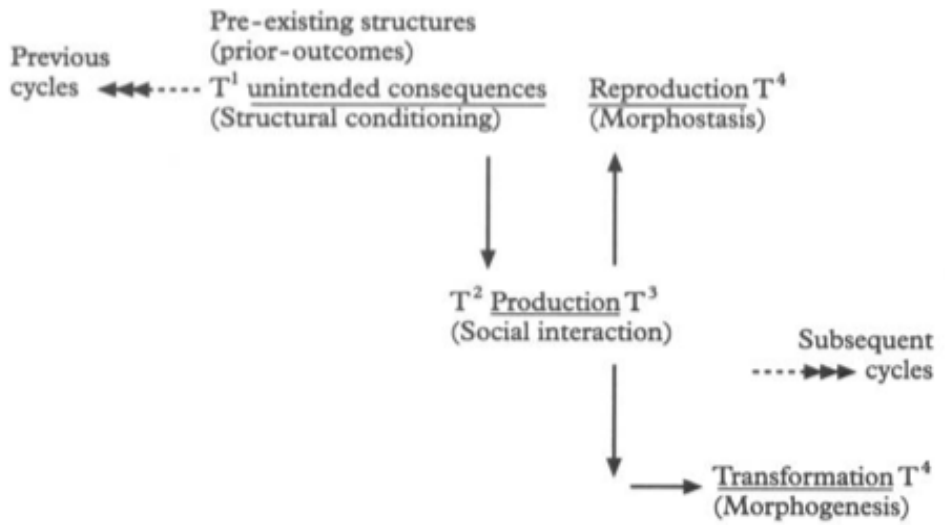

(see Archer, 1995: p. 158) 
In the figure, $\mathrm{T}^{1}$ refers to the accumulated structural conditions that are engaged at the point of activity $\mathrm{T}^{2}$ and $\mathrm{T}^{3}$ resulting in elaborations that can either contribute to the reproduction of conditions or transformation of them at $\mathrm{T}^{4}$.

Expressed in this fashion the approach can seem stark. ${ }^{\text {iv }}$ But the point is to provide clarity from which complexity can then be developed as actual processes are traced in concrete research. Moreover, the complexity extends also to the nuance of the concepts as they are used (see e.g. Archer, 2012). For example, some aspects of social interactions may lead to degrees of transformations of some practices and conditions whilst simply reproducing some other aspects. The phrase 'unintended consequences' is not intended to imply that accident accounts for forced labour. This would be incompatible with the core issues of coercion/deception and entrapment. Nor is the focus in terms of forced labour here on vulnerability, choice, and agency intended to reduce the problem to the individual victim as though they were somehow the only appropriate level of analysis or were somehow to be considered culpable regarding their situation. The point is to briefly set out how social theory can provide a useful way to trace the actual development of forms of forced labour that directly confronts the tension between determinism and contingency and is consistent with the Marxist insight that wo/men make history (see here also Brown et al 2002; Callinicos 2004; Joseph, 2006). In conducting actual research on forced labour the use of a heuristic to trace the actual complexity of agency-structure is extremely valuable (e.g. Morgan and Olsen 2011b). That complexity, moreover, is able to trace mixes of characteristics for individuals and households and also for work practices and is thus able to directly focus on the perpetuation and innovation of forms of forced and unfree labour within capitalism. This does, however, further beg the question what type of capitalism creates and exploits vulnerabilities through forced labour (and also other forms of exploitations). What is it about modern capitalism that enables opportunity to exist?

\section{Traits and trends of modern capitalism and forced labour (you are responsible for everything we do to you)}

The debate in development studies regarding unfree labour highlights that capitalism can be more or less exploitative and that the exploitation can extend to forms of forced labour. There is a tension created in the sense that it is free labour that is central to capitalism in the abstract as an economic and an ideological form. However, the profit motive and the way in which socialisation occurs in capitalism encourage this tension to persist rather than disappear. Forced labour is an ever-present possibility within real historical capitalism, but it would seem more likely within some forms of capitalism than others. A capitalism which encourages distanced, de-moralised and instrumental relations, which encourages a view of people as economic units (means rather than ends) and often as disembodied unit costs in an accounting culture, dehumanises being and thus provides a conducive mentality for extreme forms of exploitation or for simply ignoring such forms of exploitations or for placing them in inappropriate conceptual contexts (they are someone else's responsibility, they can be subsumed or disguised within general market logics as simply transactions or as distortions or as development necessities). Neo-liberalism is this kind of capitalism (for various aspects see Harvey 2007, 2011; Kiely, 2005; Jessop, 2001, 2007, 2012; Desai, 2013; Walker, 2008).

Ironically neo-liberalism, with its formal focus on the free individual is simultaneously conducive to forms of extreme exploitation and forced labour. It is a form of capitalism with a legitimacy contradiction. Capitalism in general and neo-liberalism in particular, must formally oppose forced labour yet neo-liberalism would seem to be conducive to such forced labour. Though there are many who work in good faith to eradicate forced labour, it is not plausible to consider it an accident within neo-liberalism, its multiple manifestations, extending to perpetuation in some sites and emergence in others, makes forced labour more plausibly a consequence of neoliberalism's form.

Neo-liberalism is a system that starts from a highly reductive economism. It seeks to expand the sphere of economic logic to all aspects of existence based on an ideological expression of free market competition matched to a reality of large corporations. It is one where power is operative in adverse ways and is one that: 


\section{Pushes for light touch regulation and self-regulation in given geographies as markets}

Basic institutions plus the flow of information are supposed to discipline markets, but limited oversight combined with growing complexity means information cannot readily serve its stated function - limited information, disinformation and disempowered information can be the reality. Forced labour can then flourish whilst being formally repudiated within basic institutions.

2. Espouses the desirability of open borders for the free movement of labour, goods and capital and then delivers not quite open borders and not quite free movement of labour, goods, and capital

Open borders encourage the movement of labour as migrants, but not quite open borders also channels some migrants into the hands of traffickers; open borders encourage the trade of goods and the flow of capital to sustain the production of those goods, but equally encourages low commitment capitalism where unit cost oppression creates downward pressure on wages, conditions, and standards, creating a 'bottom of the market' logic for the use of forced labour; in this context the free movement of capital is the threat of the outflow of capital, providing a disciplining force that surreptitiously encourages the use of forced labour; the profits from forced labour, meanwhile, benefit from the development of multiple institutions and organizations designed to facilitate the flow of capital, where that flow has built-in mechanisms to evade regulation, oversight, and the payment of taxes, duties and so forth; as such, any attempt to block the profits from forced labour find themselves working against the direction of development of the system in general, rendering this aspect of preventing forced labour more difficult; the system itself has multiple conduits for the flow of extracted wealth, via tax havens, the operation and advisory services of universal banking and so forth; forced labour is encouraged because profits can be made, moved and protected.

\section{Incrementally shifts towards 'financialization'}

Corporations become financial units owned, operated and influenced by financial organizations (private equity, hedge funds, banks) creating a new layer of interests and distance between ownership production and labour. This leads to a further reduction in commitment from capital, and to greater pressures on wages as shareholder value and wealth extraction increase and corporations become mere interchangeable financial instruments. New uses of and markets for debt create an unstable system of inequalities but also leads to the financialization of everyday life as debt, consumption, and commodification spread into the household. ${ }^{\mathrm{v}}$ Financialization facilitates forced labour because it exacerbates the tendencies in $1 \& 2$.

\section{Is orchestrated through global governance organizations because globalization is also a multifaceted expression of capitalism}

The push for light touch regulation and self-regulation, for open borders, and the spread of financilization affects given geographies but with a broader systemic logic which makes possible specific systemic configurations on a global basis, such as long supply chains, outsourcing, and sub-contraction. The reality of IMF and WTO practice is the enforcement of market interests. It is the distancing and low commitment inherent in a major strand in this activity that facilitates exploitation and forced labour where least cost becomes a major consideration. This least cost basis can encourage informal economy relations despite the notional existence of a formal economy. ${ }^{\mathrm{vi}}$ The real institutional base is then one that deviates from its formal statement and structure; the enforcement of standards in work, for example, deviates from its statement, and a whole human infrastructure of corruption can emerge focused on maintaining the fiction of compliance (whilst the resources allocated to exposing the real problems, providing education in their regard, and eradicating them remain low). The institutional basis of developed states can simply be blinded to this effect (as a particular expression of the dynamics of limited information, disinformation and disempowered information). The institutional basis of developing states, meanwhile, can be deformed even as the state supposedly takes on aspects of the governance profile of 'advanced' capitalist democracies; within neo-liberalism it is the capitalism rather than the democracy that dominates. In so far as this is the 
case, instrumentalities and brutalities can proliferate and so forced labour can develop even as a given state develops; the very notion of development is confused and deformed and this is often disguised because the consequences are seen as preferable to what came before and are considered temporary in a system in transition, yet neither point is an adequate justification for preventable forms of exploitation now, ${ }^{\text {vii }}$ neither point recognizes that the forms of extreme exploitation, including forced labour, are a product of the new capitalist relations (which extend to the full system beyond the state and including the advanced capitalist economies, that calls them forth) and neither point recognizes that extreme exploitation including forced labour remains an ever present possibility thereafter.

\section{Develops along technocratic grounds}

The neo-liberal system is one that transposes every social issue into an economic framework and thus the sphere of democratic debate and control is steadily reduced and shaped in its perspective regarding the scope of appropriate conduct; issues like forced labour are delegated, becoming areas of special interest addressed by task forces and policy units who must then compete for attention and resources. The urgency of the issues, the sense of personal responsibility is then suppressed even as the problem is identified and addressed. At its most extreme, opposition to forced labour becomes marketised, becomes a lifestyle choice, a form of identity politics constructed through consumption - through what is not consumed; but the very fact that one must make additional efforts to not consume indicates both that the general systemic dynamics of neo-liberalism facilitate forced labour and that there is a contributing fragmentation of any real momentum for the eradication of forced labour within societies.

So, neo-liberalism is not required for forced labour to occur but one might argue that forced labour does more than merely occur in a neo-liberal period. The dynamics of the system create opportunity and the socialisations of the system facilitate a mentality in which opportunity becomes reality. The UN and the ILO work to eradicate forced labour and most states have enacted legal prohibitions. At the same time, neo-liberalism is a form of capitalism that places its great weight of emphasis on Berlin's freedom from (the removal of state interference or sanction in everyday life), which simply exacerbates inequalities and the potential for exploitations. Formal freedom is more easily subverted in such a system. There is a practical pitilessness to neo-liberal reality that our humanity as species being struggles with. Its core-unspoken ethos is 'you are responsible for everything we do to you'. This may have thresholds based on legal codes, formally condemning and making illegal forced labour, but the ethos helps to produce exploiters, complicity, and systemic opportunities for exploitation based on profitability and pressures to be profitable. This is so for different kinds of forced labour in different ways. Commercial sexual exploitation requires de-humanisation, it requires the objectification of the individual in order for degradation (or delusion regarding such degradation) to occur. Sexual mores and gender dynamics are significant here, but so is the basic sense of commodification and of instrumentality, which neo-liberalism encourages to a degree that far surpasses the prior period of the Keynesian consensus - the sex industry has never been more industrialised. ${ }^{\text {viii }}$ Economic exploitation is also facilitated by various generally recognizable systemic traits and trends that create opportunity. Forced labour is part of modern day business in a neo-liberal world. According to an ILO report:

Operators using slave labour in Brazil are not, for the most part, isolated landowners or owners of oldfashioned estates. They are, in fact, entrepreneurs working in agribusiness, many of them using cutting edge technology in the production phase. When it comes to the cattle-farming business, the livestock are given much better treatment than that received by labourers, including a balanced diet, computerized vaccination systems and artificial insemination. The temporary workers on the same estates are denied clean water, food prepared in hygienic conditions or adequate housing. They are constantly subjected to verbal and physical abuse, and are prevented from returning home. (Costa, 2009: p. 43)

\section{Conclusion}


As the ILO re-estimation of 2011 indicates, forced labour is not going away. The existence of forced labour highlights a potential tension in Marxism based on the centrality of the concept of free labour. As Thompson notes in his critique of Althusser:

In one hundred years the intellectual universe has changed, and even those propositions of Marx which require neither revision nor elucidation were defined in a particular context, and very often in antagonism to particular and now forgotten opponents; and in our new context, and in the face of new and, perhaps, more subtle objections, these propositions must be thought through and stated once again. This is a familiar historical problem. Everything must be thought through once more: and every term must sit for new examinations. (Thompson, 1978: p. 218)

However, in so far as it is examined, the tension is more apparent than real. Actual historical capitalism is complex in a way that Marx also recognized. One can explore that complexity in terms of useful social theory contributions, such as the realist approach to agency and structure. And one can ask what kind of capitalism facilitates the perpetuation and diversification of forms of forced labour that the ILO, in particular, has recognized. In doing so, however, one must also recognize the limits of organizations such as the ILO. The ILO does extremely important work, has made genuine achievements (e.g. Costa, 2009, ILO 2012a), and is a relatively open organization that recognizes the need for critique (see e.g. Serrano et al. eds, 2011). However, the ILO is an organization that predates neo-liberalism and whose very tenets run counter to the general direction of movement of neo-liberalism. Neo-liberalism is a system in which work is conceived along standard mainstream economic lines as a disutility, but where it is simply assumed that economic growth produces more income, a shift to a skills-service economy and thus implicitly better jobs. As such, little attention is paid to the contradictions of the system in which Braverman-type deskilling coexists with new skill demands, where income inequality grows, where supposedly classless societies become more divided as the mobility conduits for the middle class are crushed, job insecurity is rife, and where corporate welfare opposes genuine mass state welfare. The point here is that much of the system is antithetical to the concept of decent work and offers the perpetual prospect of a shift for the many towards more exploitative and unwanted work conditions. Forced labour is simply the extreme of this shift. ${ }^{\text {ix }}$

The ILO, meanwhile, recognizes the importance of unions and of unions on an international basis. It recognizes that work can be more than an opportunity cost, a 'disutility'. It recognizes that work in general ought to be more than an acceptable form of exploitation, it ought to be the very antithesis of forced labour - 'decent' work. As such, the ILO embraces the social embeddedness of economy in a way that implicitly rejects the reduction of everything to marketised relations and a stark economic framework that are core aspects of neo-liberalism. Yet the ILO is not in any significant sense an organization that is systematically critical of neo-liberalism as $a$ system. In this sense it is a part of the construction of the legitimacy contradiction that forced labour represents for any variety of capitalism. If neo-liberalism flourishes then many people will not. Recent events such as the death of 411 factory workers in the collapse of the Rana Plaza building in Dhaka, Bangladesh will be repeated as tragedy and not as farce. It is an open question, however, whether neo-liberalism can survive its own current instabilities. $^{\mathrm{x}}$

\section{Notes on Contributors}

Jamie Morgan is

\section{References}

Althusser, L. (1971) 'Ideology and ideological state apparatuses', in L. Althusser Lenin and Philosophy and other essays by Louis Althusser London: Monthly Review Press

Archer, Margaret (1995) Realist Social Theory: The Morphogenetic Approach Cambridge: Cambridge University Press

Archer, Margaret (2012) The Reflexive Imperative in Late Modernity Cambridge: Cambridge University Press 
Banaji, Jairus (2003) 'The fictions of free labour: contract, coercion, and so-called unfree labour', Historical Materialism 11(3): 65-95

Belser, P. (2005) 'Forced labour and human trafficking: estimating the profits', Geneva: ILO

Bhandari, Rakesh (2008) 'The disguises of wage labour: juridical illusions unfree conditions and novel extensions', Historical Materialism 16(1): 71-99

Bhaskar, Roy (1975) A Realist Theory of Science Leeds: Leeds Books

Brass, Tom (2002) 'Rural labour in agrarian transitions: the semi-feudal thesis revisited', Journal of Contemporary Asia 32(4): 456-473

Bremen, Jan (2007) Labour Bondage in West India: From Past to Present Oxford: Oxford University Press

Brown, Andrew Fleetwood, Steve and Roberts, John (2002) Critical Realism and Marxism London: Routledge

Callinicos, Alex (1985) Marxism and Philosophy Oxford: Oxford University Press

Callinicos, Alex (1989) Against Postmodernism Cambridge: Polity

Callinicos, Alex (2004) Making History Leiden: Brill

Cohen, Gerald (1995) Self-Ownership, Freedom and Equality Cambridge: Cambridge University Press

Costa, Patricia (2009) Fighting Forced Labour: The example of Brazil Geneva: ILO

Desai, Radhika (2013) Geopolitical Economy London: Pluto

Gills, Barry and Gray, K. (2012) 'People power in the era of global crisis: rebellion, resistance and liberation', Third World Quarterly 33(2): 205-224

Ghai, D. ed. (2006) Decent Work: Objectives and Strategies Geneva: ILO

Geurin, I. Ponnarasu, S. Venkatasubramanian, G. Michiels, S. (2012) 'Ambiguities and paradoxes of the decent work deficit: Bonded migrants in Tamil Nadu', Global Labour Journal 3(1): 118142

Gouldner, Alvin (1980) The Two Marxisms Basingstoke: Macmillan

Harre, Rom and Madden E. (1975) Causal Powers Oxford: Blackwell

Harvey, David (2007) A Brief History of Neo-liberalism Oxford: Oxford University Press

Harvey, David (2011) The Enigma of Capital and the Crises of Capitalism London: Profile

ILO (1999) Decent Work Report of the Director General Geneva: ILO

ILO (2002) 'Resolution concerning decent work and the informal economy', Geneva: ILO

ILO (2005) A Global Alliance Against Forced Labour: Global report under the follow-up to the ILO declaration on fundamental principles and rights at work 2005 Geneva: ILO

ILO (2009) The Cost of Coercion: Global Report under the follow-up to the ILO Declaration on Fundamental Principles and Rights at Work International Labour Conference, $98^{\text {th }}$ Session 2009 Report I(B), Geneva: ILO

ILO (2012) Global Estimate of Forced Labour: Results and Methodology Geneva: ILO

ILO (2012a) A Global Alliance Against Forced Labour and Traffic in Persons: Key Achievements of the ILOs Special Action Programme to Combat Forced Labour 2001-2011 Geneva: ILO

ILO (2013) World Of Work Magazine Special Issue, Geneva: ILO

Joseph, Jonathan (2006) Marxism and Social Theory Basingstoke: Macmillan

Jessop, Bob (2001) ed. The Parisian Regulation School: Regulation Theory and the Crisis of Capitalism (one of five volumes); Cheltenham: Edward Elgar

Jessop, Bob (2005) 'Critical realism and the strategic relational approach', New Formations 56: 40-53

Jessop, Bob (2007) State Power: a Strategic Relational Approach Cambridge: Polity

Jessop, Bob (2012) 'History and Crisis in Theory and Practice', presentation; IPEG Conference, Birmingham University, September; original available from author

Keat, Russell and Urry, John (1975) Social Theory as Science London: Routledge

Kiely, Ray (2005) The Clash of Globalizations Leiden: Brill

Lapavitsas, Costas ed. (2012) Financialisation in Crisis Leiden: Brill

Lerche, Jens (2007) 'A global alliance against forced labour? Unfree labour, Neo-Liberal globalization and the International Labour Organization', Journal of Agrarian Change 7(4): 425-452

Mantouvalou, V. (2012) 'The many faces of Slavery: The example of domestic work', Global Dialogue 14(2): 73-82

Martin, R. (2002) The Financialisation of Daily Life Philadelphia: Temple University Press

Marx, Karl (1950) 'The Eighteenth Brumaire of Louis Bonaparte', in Marx, Karl and Engels, Frederick Marx Engels: Selected Works Volume 1 London: Lawrence and Wishart

Marx, Karl (1954) Capital: Volume One London: Lawrence \& Wishart

Marx, Karl and Engels, Frederick (1968) The German Ideology London: Lawrence \& Wishart

Millett, Paul (2007) 'Aristotle and slavery in Athens', Greece \& Rome 54(2): 178-209

Morgan, Jamie (2009) Private Equity Finance Basingstoke: Palgrave Macmillan 
Morgan, Jamie (2013) 'Hedge funds: statistical arbitrage, high frequency trading and their consequences for the environment of businesses', Critical Perspectives on International Business 9(4)

Morgan, Jamie and Olsen, Wendy (2011a) 'Aspiration problems for the Indian rural poor: research on self-help groups and micro-finance', Capital \& Class 35(2): 189-212

Morgan, Jamie and Olsen, Wendy (2011b) 'Conceptual issues in institutional economics: clarifying the fluidity of rules', Journal of Institutional Economics 7(3): 425-454

Olsen, Wendy and Morgan Jamie (2010) 'Institutional change from within the informal sector in Indian rural labour relations', International Review of Sociology 20 (3): 535-555

Palley, Thomas (2007) 'Financialisation: what it is and why it matters', Levy Economics Institute, Working Paper 525

Patomaki, Heikki (2013) The Great Eurozone Disaster: From Crisis to Global New Deal London: Zed Books

Rao, Mohan (1999) 'Freedom, equality, property and Bentham: the debate over unfree labour', Journal of Peasant Studies 27(1): 97-127

Schumacher, E. (1993) Small is Beautiful London: Vintage

Serrano, Melisa. Xhafa, Edlira and Fichter, Michael eds. (2011) Trade Unions and the Global Crisis Geneva: ILO

Thompson, E. (1978) The Poverty of Theory and other essays London: Merlin

UN (1957) United Nations (1957) 'Section I: Institutions and Practices Similar to Slavery' pp 41-42 in Supplementary Convention On the Abolition of Slavery, the Slave Trade, and Institutions and Practices Similar to Slavery, UN Treaty Series volume 266 http://treaties.un.org/doc/publication/UNTS/Volume\%20266/v266.pdf

US Department of State (2011) Trafficking in Persons Report: June 2011 Washington DC

Walker, Kathy (2008) 'Neo-liberalism on the ground in rural India', Journal of Peasant Studies 35(4): $557-620$

Wright, Erik (1993) 'Class Analysis, history and emancipation', New Left Review 202: 15-35

Jamie Morgan (Morgan J.)

Affiliation: the Association for Heterodox Economics, Co-editor Real World Economics Review, Accountancy, Finance and Economics Department, Leeds Metropolitan University, Leeds, UK

Email: jamiea.morgan@hotmail.co.uk

Tel: 86-10-85195750

Mailing Address:

Accountancy, Finance and Economics Department

Leeds Metropolitan University

Leeds, UK

LS1 3HE

Wendy Olsen (Olsen W.)

Affiliation: Social Statistics Discipline Area, University of Manchester, Manchester, UK

Email: wendy.olsen@manchester.ac.uk

Tel: 86-10-85195750

Mailing Address:

Social Statistics Discipline Area

University of Manchester

Manchester, UK

M13 9PL

\footnotetext{
${ }^{\mathrm{i}}$ The ILO acknowledges that its re-estimation is likely also highly conservative for a variety of reasons: 1) part of the methodology estimates from samples of reported cases and given the nature of forced labour those reports are likely to be a fraction of the whole problem 2) many instances are also not easily classified because of the way forced labour shades into exploitation without clear indicators of 'forced' (what makes psychological menace etc.) 3) some areas are additionally 'grey'; child labour is endemic in many poorer nations, particularly in agriculture, but countries like India exclude agricultural work for minors from their statistics, making it difficult to calculate comparable forced labour rates for children (there is also an issue created by different legal
} 
working ages in different countries). 4) The US Dept of State Trafficking in Persons Reports (e.g. (US Dept of State 2011) categorise some countries as not fully compliant with forced labour protocols based on various issues of data collection and enforcement. India, for example is currently categorised as Tier 2, meaning noncompliant with its ratification of the 2000 UN Trafficking in Persons Protocol and the Trafficking Victims Protection Reauthorisation Act 2003. The numbers of trafficked victims are increasing and the government is currently failing to provide evidence that it is making satisfactory efforts to reduce trafficking (though India was recognized for its formal commitment and 'uneven progress').

${ }^{\text {ii }}$ A useful checklist for forced labour characteristics is provided ILO, 2005: p. 6:

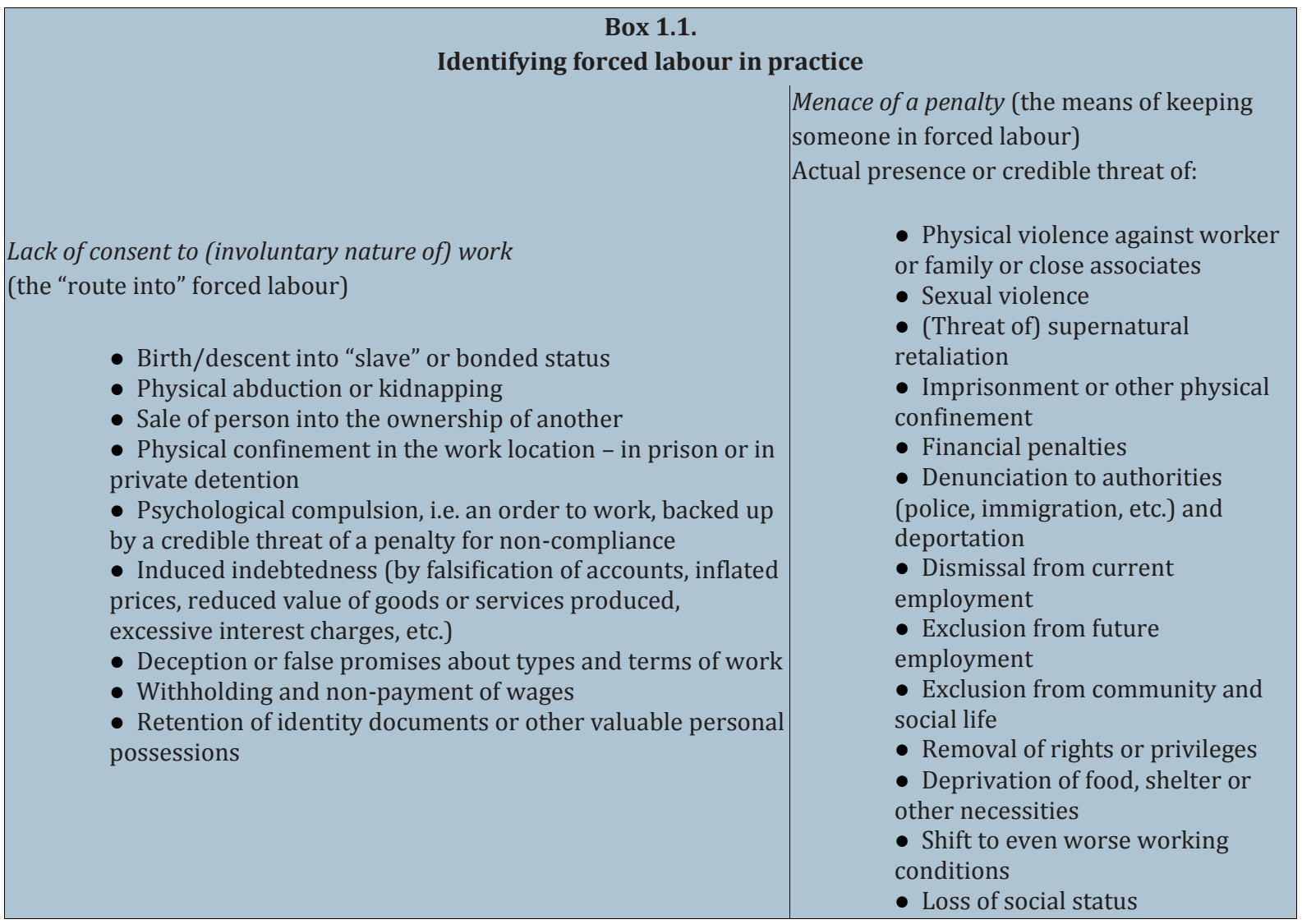

iii For example, estimates for the number of slaves in Athens after 500 BCE indicate that the slave population outnumbered the free population (though slavery categories were highly differentiated); slavery can be the dominant form of social relation in a pre-capitalist system. For discussion of how slavery was justified in Greece - with some reference to Marx from volume 3 of Capital see Millett (2007).

${ }^{\text {iv }}$ As Bob Jessop has pointed out morphogensis as a conceptual underpinning for empirical work has many advantages. Its focus on the differentiations of agent- structure brought together through temporal interactions allows one to encompass recursive conditioning, mutuality, and complex co-evolution. As such it is an effective approach to sketching out social activity. Jessop, however, prefers the strategic-relational approach (SRA) in so far as he thinks this pays greater attention to the complex mix of spatio-temporal structures and of social forces (Jessop, 2005: p. 48).

${ }^{v}$ Palley defines financialization as: 'A process whereby financial markets, financial institutions and financial elites gain greater influence over economic policy and outcomes. Financialisation transforms the functioning economic systems at both the macro and micro levels. Its principal impacts are to 1) elevate the significance of the finance sector relative to the real sector, 2) transfer income from the real sector to the finance sector and 3) increase income inequality and contribute to wage stagnation.' (Palley, 2007: 3). For a Marxist analysis see Lapavitsas ed. (2012); for its pervasive social consequences see Martin (2002); for the impacts of financial organizations on corporations and labour see Morgan (2009; 2013)

${ }^{\mathrm{vi}}$ The ILO for example highlights this beginning from: "The term "informal economy" refers to all economic activities by workers and economic units that are - in law or in practice - not covered or insufficiently covered by formal arrangements. Their activities are not included in the law, which means that they are operating outside the formal reach of the law; or they are not covered in practice, which means that - although they are operating 
within the formal reach of the law, the law is not applied or not enforced; or the law discourages compliance because it is inappropriate, burdensome, or imposes excessive costs.' (ILO, 2002: p. 2)

vii The most prominent area of debate and disinformation here is probably child labour in the developing world. The argument that child labour is an alternative to poverty is self-serving. Children become labourers because of the poor terms and conditions offered in general to the most vulnerable in society. It is the collective impoverishment of classes and castes that leads to child labour. Furthermore, child labour is not typically necessary in order to meet an explosive demand for labour within the economy. Child labour is preferred because it is cheap and can be exploited. It is part of the way in which the terms and conditions of adults are reduced and it is part of the reason why there is often adult urban unemployment. Forced child labour has become a constituent in the inequalities of development that are typical of, for example, the Indian economy. It has done so because structural relations maintain the vulnerability of some to forced labour work patterns and because those relations have carried over into new contexts as the Indian economy has changed.

viii As is well documented, economics does not deal well with issues of ethics, morals and systems and this is not new to neoclassical theory as a main legitimation for neo-liberalism. Schumacher, for example, in developing the concept of natural capital and arguing for decent work is highly critical of Keynes' essay 'Economic possibilities for our grandchildren', which argues that self-interest (vice and selfishness) are necessary to promote growth in order to achieve a better society later. Keynes could easily be caught in a contradiction regarding labour standards and the existence of exploitation here (see Schumacher, 1993: p. 18) [I thank Victoria Chick for this point].

${ }^{\text {ix }}$ One should recall Erik Olin Wright here on the rise and contradictions of modern capitalism as a challenge to Marxism in the wake of the collapse of the communist states: 'there is the political challenge posed by the dramatic historical developments of recent years, which call into question the feasibility of a critical theory normatively anchored in socialism. Some people might think that these challenges will ultimately lead towards a dissolution of Marxism as a coherent intellectual tradition... While there may be no going back to the confident assurances of Marxism as a comprehensive paradigm of everything, it is also the case that any serious attempt to understand the causes of oppressions in order to enhance the political projects aimed at their elimination must include as part of its core agenda the analysis of class. (Wright, 1993: p. 23)

${ }^{x}$ Scholar-activists, such as Heikki Patomaki or Barry Gills argue that the recent crisis within neo-liberalism may well have exacerbated the immediate problems of labour but that the historical moment also provides a new opportunity for progressive social movement responses to the inherent instabilities of neo-liberalism. Patomaki, in particular, is of the opinion that neo-liberalism will not survive long as a system (see e.g. Patomaki, 2103; Gills and Gray, 2012). 